\title{
The Waqf Management: Perspective in Comparison
}

\author{
Abdul Mubaraq \\ Institut Agama Islam Assadiyah Sengkang Indonesia \\ bara.lingara@gmail.com
}

\begin{abstract}
Waqf is an important instrument to improve welfare. Traditionally, the object of waqf is land. However, as civilization develops, waqf objects also need innovation because of limited land. This innovation also needs to be balanced with quality management. This study compares perspective of waqf management by three institutions in Province Yogyakarta Indonesia. They are Nahdlatul Ulama, Muhammadiyah, and Badan Wakaf Indonesia. This study uses explorative qualitative techniques. Data was obtained from interviews and documentation. Data analysis by coding techniques (breaking coding, pivot coding and choir coding). The results of the study found that (a) the management of waqf by Nahdlatul Ulama has not been managed properly legally administrative; (b) the management waqf by Muhammadiyah has been managed legally administratively; (c) the management and utilization of waqf by the Badan Wakaf Indonesia is well managed legally.
\end{abstract}

Keywords: Waqf Management, Perspective in Comparison

\section{A. INTRODUCTION}

One of the parts Islamic economic to increase welfare is management of ZISWAF (Zakat, Infaq, Shadaqah and Wakaf). In the field of social and economic, Islam encourage utilization of waqf institutions in order to increase the general welfare of its. Muhammad Musthafa Tsalabi have made the formulation of waqf. The concept is the detension of the property of a person who represents and donates the benefits for the purpose of goodness.

Waqf are defined as the detention of a proprietary to the things that even (al-ain) for the purpose of it by way of a benefit or to be gained by it (al-manfa 'ah) (al-jurjani: 328). In other hand, in fiqh books the clergy differing views in providing understanding waqf. The discrepancy could bring due to different to the law of inflicted. waqf definition according to the people of the fiqh is as follows .

Waqf is one of religious organizations have rooted old in the traditions of a society muslims. In Indonesia, waqf has become main supporting in the community development, especially muslim. Almost every house, education facilities Islam and religious other islamic institutions built on land waqf. The Qur'an shows that the return for someone to 
spend in the way of Allah, such as a seed grows to seven and in each ear a hundred grains (Qs.Al-baqarah 2: 261).

Research of Ismawati (2007), who discovered that there are many found their waqf mosque the great who inhabited illegally by the community. Based on it, the author felt that one of root problems on soil management difficulties have waqf caused by differences in understanding of manage land waqf. This can be seen from many problems on the management of the waqf. A lack of understanding about the role and responsibilities nadzir in managing the waqf in addition and cannot be viewed the eyes. Particularly, in terms of the need to integrate serious administration policy, it is not just a social to avoid conflicts for the purpose of short term but also for the long term objective of which is to push forward the generosity and strengthen civil society .

\section{A.1 Nahdlatul Ulama and Muhammadiyah as The Biggest Islamic Institution in Indonesia}

Indonesia has two institutions largest the islamic Nahdatul Ulama (NU) and Muhamadiyah. The two islamic mass organizations that would push great potentiality is management and develop a range of management model religious or community use to funding the fact that only the organization as well as an increase in the general welfare of its in the field of education, health and social-economic. Each Islamic mass organizations support for violent attacks had entrusted bakrie sumatra plantation tbk be possible to describe different views about for religious or community use as well as it is implemented, the result of these two mass organizations said the head that would push the ideology of as well as a method of the thinking different bit. It is so important under review in detail, so that the stigma of the public related to the views of distinction from ormas-ormas Islam this could be union all muslim people in the . Not only it self with the interests of or group individual so they can be, however the settlement of the problem for religious or community use result the following key issues community can settled by many considerations and in the sight of each a figure by islamic mass organizations which he believes are.

Besides NU and Muhamadiyah, the government also involved in the management of land waqf.This can be seen from the emergence of government regulation number: 28 of 1997 on perwakafan land belonging to article 1 paragraph (1) that also the compilation of laws islamic article 215 expressed : 
"waqf is legal action a person or group person or law agency that separates some of objects her and melembagakannya forever to the interests of synagogue or public use other in accordance with the teachings of islam".

Based on it, researchers interested to have a research aimed at know the management and land use waqf based on perspective NU, Muhammadiyah and the government Yogyakarta. Spesificallly, the formulate problems are; 1) How the management and land use waqf based on perspective NU in Yogyakarta; 2) How the management and land use waqf based on perspective Muhammadiyah in Yogyakarta; 3) How the management and land use based on goverment waqf perspective in Yogyakarta.

\section{B. DATA AND METHOD}

The Method was used in the study design qualitative research was conducted with the approach explorative. The research is of the preliminary study with locate and identify views islamic figures $\mathrm{NU}$, Muhammadiyah, and the government argument about the perspective of the management and the use of waqf land. In explorative research, it is also added that the building blocks to play an active role in the process of research. Next building blocks select among the patterns remain the same research in keeping with the theme or title research that which is lifted. Related to the topic of the problems that solved in this research, so a pattern that would be run is of many patterns experience survey, namely research technique explorative in the form of a discussion or interviews with individual regarded got the better of a particular field who are the objects of research.

As for a pattern above research aimed at expressing a view islamic figures NU, Muhammadiyah, and the government. The design this research will be unveiled things that have not yet thought of by building blocks so that the result of research can be more detail and can respond to the problems that researched.. The total sample from the study three people, a figures of NU, a figures of muhammadiyah, and a government. As for the criteria for samples to be taken from mass organizations namely from each of the tribunal waqf and property Muhammadiyah, NU waqf institution namely Lembaga Wakaf dan Pertanahan Nahdlatul Ulama' (LWPNU), and government agencies who manages the land of waqf. Then, so that it would be more representative samples to be taken, so sample 
criteria more reconfirmed, namely by her to take samples from islamic NU figures, Muhammadiyah and the government have been exposed to this waqf in general.

An instrument in this research is the notion Islamic figures NU, Muhammadiyah, and the government for the management and the use of waqf land. In this research used an instrument research with the use interview. This was due to because authors want to get data directly taken of Islamic figures. NU, Muhammadiyah, and government pertaining to the problems waqf land. The instruments developed and made in the form of the questions relevant as guidance for an interview. Technique data analysis using a technique encoding (breaking encoding, pivot coding and select coding).

\section{RESULT AND DISCUSSION}

\section{C.1 Perspective of Waqf Management by Nadlatul Ulama (NU) Yogyakarta.}

According to NU that village communities assume that waqf only waqf of immovable asset, but there are basically waqf productive and waqf of cash transfer (Undang-Undang No. 41/2004 about waqf). Certaintly, this was due to the because the community so far endowment land for an activity of worship and the lack of socialization of the authorities that is the government so that so far had not yet reached levels of society especially nazhir and community leaders .

In addition, to the management of waqf NU not based laws and rules. This is because the regulations which waqf regulates, it is no wonder if the development of waqf in Indonesia experienced stagnation. Although, quite a lot of institutions waqf standing, but only a small institutions waqf (nazhir) are able to manage their possessions waqf optimally. Based on it it is perfectly natural to NU said that the management of waqf now it has not been conformity to law and the existing rules. For example problems sometimes found in an institution waqf namely of limitations that are owned nazhir to understand the contents of the act of waqf thoroughly. This may cause the management of waqf that were not in accordance with existing laws and the existing rules.

Management and the use of waqf during this is what happened in NU management is far is said both, because LWPNU own behind in take care of waqf that is in Yogyakarta, so that NU managing in management. During this waqf land by apportioned in the form of governance by LWPNU mosque. It cause most people who endowments land into LWPNU only to established according to the community that mosque because he is punished for 
flowing on a continual basis so the utilization of waqf in Yogyakarta only to a place of worship.

Currently, LWPNU an effort to undertake of collecting data on how much land in the governance by LWPNU, in addition LWPNU are pushing for communities have concern to take care of waqf that by which so far waqf land by apportioned governance there are few who do not have a certificate. Because, only handover for granted, so that LWPNU an initiative to hold assistance to people who want to or took the initiative to process the land certificate the waqf.

According to NU waqf benefits to the economy Indonesia and poor people in reality is very small, formerly LWPNU having a program that is collecting fund from public that by which is what it looked like in the form of money each of which the value is in the Rp 10.000 - millions of rupiah, one in which the result to help the productive namely by lending to the traders are the market and angkringan whose intended targets in yogyakarta without collateral and when your words come true bad debts that will replace the current management LWPNU itself.

Waqf is a means of potential to empower local people who are less fortunate, if waqf are not managed maximally, so a form of the benefit of waqf itself was limited to the mosque without the establishment of community social provide solutions to the problem. Related to the cleric waqf, NU hope land is in Yogyakarta namely the public having a sense of awareness in conducting its legality and all parties both leaders or institutions, the social organizations and the government to support the waqf of land. NU role in helping the administration waqf dust and set a good example to the public. Socialization and in predicted by LWPNU against waqf land, that is always done socializing the information must be, because there are still many community members who do not know the importance of about legal law or land certificates waqf can be done by a great variety of as recitation or the assembly.

The expected results over waqf land when socialization and the applications are good, so the results also good so that it can result in something useful for the community in general especially muslims that is in Yogyakarta and the number of waqf land becomes more increase from year to year.

\section{C.2 Perspective of Waqf Management by Muhammadiyah Yogyakarta.}


According to Muhammadiyah Yogyakarta that land on Yogyakarta the year are a little and the donate in the form of land have decreased. For that Muhammadiyah have the initiative in development waqf land in the form of waqf cash. In order to support things is all necessary resources qualified ensure that the management of waqf can be carried out maximum.

Muhammadiyah views on the management of waqf, is in accordance with regulations and the law in force. Muhammadiyah do cooperation with Indonesia Waqf Agency (Badan Wakaf Indonesia/BWI) and national defense waqf registration procedures and that has been implemented in Muhammadiyah, there are procedures have been in line with pasal 32 UU No. 41 tahun 2004 jo pasal 38 pp no. 42 tahun 2006 jo pasal 10 pp no. 28 tahun 1977 jo pp no. 6 tahun 1977.

This is because any regulations that set about waqf therefore the development of waqf in Yogyakarta a Muhammadiyah experienced an increase in governance. Of a certain quantity of land waqf that is mastered Muhammadiyah almost mostly used to build the for the worship of 170 for the location, Mushollah at 60 locations and place to education of as many as 114 location and as much as 23 locations used to social as well as an orphanage, a boarding house, the hospital and the office of Muhammadiyah. This is all help the government program in educational sector or school for example and health and economic. The utilization of waqf have not optimally run, because there are still many their waqf who not yet used or unemployed or did not productive. This is caused by the limitations of the resources (human resources) itself in managing waqf assets .

The waqf in Muhammadiyah very rapidly, a lot of land waqf new ground, the number of broad and it is very good. But, how many land waqf owned Muhammadiyah still had not certified. When its left too long it will cause new problems in the future, seen from research talk about land disputes waqf in Indonesia where research So'ima (2006).

The issue of land waqf in Yogyakarta is the lack of evidence of legal handover of waqf. Therefore, when the waqf provider dies, there will be potential problems with the heirs The management of waqf conducted the tribunal waqf and property Muhammadiyah an effort to undertake repairs through the online system which is that the system can register waqf that entered the account of land and land that have been in the gates of the maximum governance so that land lots which have been can be in the governance with whether good or if increase. 
According to the court of representative representation and Muhammadiyah, that is land not as social land but rather as business because the problems that are found especially in Yogyakarta, there are several unscrupulous extremely vociferous buying land to the community business. It is therefore the tribunal waqf and property Muhammadiyah anticipate by doing sosialisai about waqf of cash are where the result of waqf cash may be allocated to the alienation of land.

The socialization of the program is hoped that people can understand more and understand about waqf because often found among the community that one who waqf one who own land but basically waqf is waqf productive and waqf of cash so that people who do not have any land can berwakaf with one of them is waqf cash.

Results in expect over waqf land when socialization and the application good, so the results also good so that it can result in something useful for the in general especially muslims that is in Yogyakarta and the number of waqf land becomes more increase from year to year.

\section{C.3 Perspective of Waqf Management by Indonesia Waqf Agency (Badan Wakaf Indonesia/BWI) Yogyakarta.}

According to BWI Yogyakarta the development of land waqf and limited only to inform the development of immovable asset namely waqf the ground so that progression waqf cash and productive very small. In addition the impediments that were found dumped in management waqf agency in Indonesia at special in Yogyakarta, that is the problem the budget where the budget for the development of very small waqf so the BWI office-holders can only maximize budget leads to better one of them is socialization to the community .

The waqf based on laws and rules, the waqf indonesia argued that it was run as laws and rules, for the ministry of religion always do socialization the law waqf and government regulation of waqf. But with little understanding by the community of regulations which govern waqf, so it is not surprising that there are still many land waqf especially in Yogyakarta.

In addition even though quite a lot of institutions waqf that stands, but only a small minority of institutions waqf (nazhir) are able to administers the estate of objects waqf in an optimum manner. As for example problems sometimes found in an institution waqf, namely of limitations that are owned nazhir to understand the contents of the act of waqf 
thoroughly. This may cause the management of waqf that were not in accordance with existing laws and the existing rules. But in terms of quantity good enough, having been demonstrated at the rising land assets and the number of wakif who was always going to grow, this proved that the development of waqf in terms of quantity enough reliable but limited only to inform of immovable asset that is, land .

While the benefits of waqf for Indonesia economic and poor people in real terms, according to agency figures view waqf Indonesia said that, waqf have assist the economic Indonesia in terms religious facilities because so far the waqf what that adjacent property is Yogyakarta only in use for places of worship places and have not been able to managed with maximum. But, basically waqf is facility potential to empower poor people, but when waqf are not managed to the full, then a benefit from waqf itself limited only to the establishment of islamic and mosque without giving solutions to social problems.

Seen from the potential waqf at this time, added on the models the development of waqf that has been adjusted in the days of and condition of a community, then the distribution of wealth waqf right on target or their needs. It is very possible once, that waqf can help the economy and give benefit in real terms for people who need. Hence to back it up all necessary resources qualified ensure that the management waqf can be done in full. Until now, waqf is on a waqf Indoneisa Yogyakarta has not experienced the development of very good.

That is why it is, duty BWI Yogyakarta to provide agricultural extension services for the nazhir mosque and manager of a mosque in order to optimize waqf in a productive way and to optimize the use the potential waqf cash. One of the examples was the development of waqf in Muhammadiyah is very fast, a lot of the new land of waqf, in terms of quantity broad and the number was very good. Muhammadiyah has had various asset in the form of school, starting from the the kindergarten school is up, and the hospitals derived from soil waqf scattered throughout Indonesia. This is all very help the government program especially in the health and education sectors as well as economic. Understanding waqf contained in Undang-Undang no 41 tahun 2004 about waqf article 1 is

"waqf is legal action wakif to separate and / or give you his wealth to use forever or certain period in accordance with their interests to their temple and / or public welfare according to the shariah", besides article 5 is 
"Possessions waqf is property have a durable and / or long term benefit and has economic value according to a shariah diwakafkan by wakif ".

Meanwhile, the use of their waqf can be used to positive things and productive. The waqf in Islam according to the documentation Al-Imran verse 92 saying :

"You never not until to good (perfect), before you spend whatever you love and whatever you spend, god knows it " and in the history of the muslim if saying "if you will, you hold the property and you sedekahkan the results".

The waqf as al-worship and al-maliyah there is no explicitly in Al-Qur'an. Excavation legal scholars waqf done with elaborating on implicit messages in Al-Qur'an and realy on text if you will. If the waqf theorems related ijmali or common is legal. But the law is the waqf as if it was the result of ijtihad, because the law waqf is not charity, donation to charity and waqf accentuated the legal base from 2004 in Undang-Undang No 41 Tahun 2004 of Waqf, Peraturan Pemerintah No 42 Tahun 2006, on The Implementation of Undang-Undang Tahun 2004 no 41 of waqf.

According to the opinion on the law of the subjects waqf in Indonesia, most say come because there laws. From here, can be seen that better than Nahdlatul Ulama, Muhammadiyah and BWI at least most know that waqf has been is support from state law that laws. And laws act was subsequently greatly needed as legal protection and legality of waqf. Besides the laws about waqf as legal protection, is expected to unite thinking about waqf figures, so the development of waqf land in Indonesia especially in Yogyakarta would be much better.

On the point is anyone can do waqf not to be rich, and reward and benefit to the community. In addition to the community to waqf opportunities, then the person will feel more comfortable waqf because will fear no more will lose their wealth in forever, and wakif could control the use of their wealth to the needy. Previous explanation about a statement "anyone can waqf $i$ would not say rich" when understood from the interpretation of it, so waqf cash and productive could be an alternative for people who want to waqf but you have but little power of their wealth. Then the community did not need to worry anymore will lose their wealth in forever. In addition they will get two things, the first reward waqf over property. The second, what fully used to still be used for the benefit of his relatives and his community broad. 


\section{CONCLUSION}

Based on the research done, so the conclusion in research this then if they testify:

1. Management and land use NU waqf in Indonesia especially in Yogyakarta are not managed well because most wakif submit to nazhir only with the handover agreement without applied with adminitrasi are legally and evidence certificates. Although law waqf the ground in islam only consist of wakif, nazhir, and witnesses have allowed of pledge waqf, but the administration is also very important in pledge waqf. In addition the acquisition and the management of waqf land NU in Indonesia at special in Yogyakarta was generally of the awareness and concern that people will have in caring for administrative details. Meanwhile, in terms of the use of land some waqf most as a place of worship.

2. The management and land use waqf Muhammadiyah in Indonesia has already started to well-developed especially in the field of management and acceptance of waqf who have been doing pickup waqf is in accordance with existing regulation is taking away of justice and. Although in reality most waqf Muhammadiyah are still earth but waqf money and productive waqf also accepted. According to Muhammadiyah, the waqf of land from someone who gives waqf in the form of land a little more land narrowing because of a sinus, so that land has then Muhammadiyah provide financing was done in coordinated with through waqf cash, while the management of waqf ground according to Muhammadiyah are already operating well although the of human resources (office-holders) still needs to be improved. Meanwhile, in terms of the use of waqf of sod used to helping empowerment of the surrounding community and assist the economic Indonesia

3. Management and land use waqf BWI especially in Yogyakarta progressed but are limited to things that did not move ( land ), it is proven with the increase the temple in Yogyakarta from the waqf. The waqf the ground in islam highly recommended to muslims law and although the way it is set in laws and government regulation. The waqf further land in a body of waqf Indonesia and it does not move fixed number has decreased because the ground is what it looks like, when in waqf also known waqf money or waqf cash, while the management of waqf land in Indonesia at special in yogyakarta are already operating in accordance with the laws and regulations there are, but socialization activities on the management of waqf in Yogyakarta still needs to be improved especially in administrative land certificates waqf. Meanwhile, in terms of 
the use of waqf land was used as a place of worship as mosque, while waqf productive soil is weak and the need for socialization to the community about waqf productif and waqf of cash.

\section{Reference}

Amin, Nugroho, M Yusuf . 2012. Fikih Al Ikhtilaf NU Muhammadiyah. Wonosobo: Ebook Free.

Azwar, Saifuddin. 2001. Metodologi Penelitian. Yogyakarta: Pustaka Pelajar.

Badan Wakaf Indonesia. 2013. Himpunan Peraturan Perundang-Undangan Tentang Wakaf di Indonesia. Jakarta: Badan Wakaf Indonesia

Boedi, Harsono. 2005. Hukum Agraria Indonesia : Sejarah Pembentukan Undang-Undang Pokok Agraria, isi dan Pelaksanaannya, Djambatan, Jakarta.

Febriansyah, Erfin. 2008. Tesis: Peranan Persyarikatan Muhammadiyah Sebagai Nazhir Dalam Pengelolaan Tanah Wakaf di Yogyakarta Menurut Undang-undang Nomor 41 tahun 2004 tentang wakaf. Universitas Dipenogoro Semarang

Hamzah. Pengembangan Makna Objek Wakaf dalam Fiqih Islam dan Hukum Positif di Indonesia (Kajian Tentang Perluasan Fungsi dan Kewenangan Peradilan Agama dalam Menyelesaiakan Sengketa Wakaf).

Ismawati. 2007. Penyelesaian Sengketa Tanah Wakaf Studi Terhadap Tanah Wakaf Banda Masjid Agung Semarang. Masters Thesis, Program Pascasarjana Universitas Diponegoro.

Kementerian Agama Republik Indonesia. 2013. Himpunan Peraturan PerundangUndangan Tentang. Jakarta: Kementerian Agama Republik Indonesia

Medias, Fahmi. 2017. "Bank Wakaf: Solusi Pemberdayaan Sosial Ekonomi Indonesia." Indonesian Journal of Islamic Literature and Muslim Society. Vol. 2. No.1.

Niam, Khoirun. 2012. Ormas Islam dan Isu Keislaman di Media Massa. 
Lembaga Penelitian Dan Pengabdian Masyarakat Institut Agama Islam Negeri Sunan Ampel Surabaya

Peraturan Pemerintah Republik Indonesia Nomor 42 Tahun 2006 tentang Pelaksanaan Undang-undang Nomor 41 Tahun 2004 tentang Wakaf.

Saepuddin, Asep. 2012. disertasi: Reinterpreting Islamic Norms, The Conflict Between Legal Paradigms and Sosio-Economic Challenges (a case study of waqf and zakat in contemporary Indonesia). Universitas Islam Negeri Syarif Hidayatullah Jakata.

Seto, Aji, Mohamad. 2011. Tesis: Pendapat Hukum Pengurus Majelis Tajrih dan Tajdid Muhammadiyah dan Pengurus Lembaga Bahtsul Masail NU terhadap Pasal 28 UU No 41 Tahun 2004 Tentang Wakaf Tunai di Kabupaten Banjarnegara. Universitas Islam Negeri Sunan Kalijaga Yogyakarta.

Strauss, Corbin. 2003. Dasar-dasar Penelitian Kualitatif: Tata Langkah dan Teknik. Yogyakarta: Pustaka Pelajar

Undang-undang Republik Indonesia Nomor 41 Tahun 2004 tentang Wakaf 